\title{
Correspondence
}

\section{Early retirement on mental health grounds}

Sir: I am referring to Dr Pastor's (Psychiatric Bulletin, November 1995, 19, 705) letter. I too have been asked to prepare psychiatric reports for early retirement where the individuals concerned have not been treated for their condition. I am also concerned by the untreated people I am asked to see for personal injury claims following road traffic accidents or work accidents. They seem particularly reluctant to report psychiatric symptoms to their general practitioners.

It is espectally difficult to reach out to these people with government-led pressure on purchasers to provide services for psychotic disorders above all else.

\section{N. LONGHURST}

Fair Mile Hospital, Reading Road, Cholsey, Wallingford, Oxon OX10 9HH

\section{Assescment of insight}

Sir: Assessment of insight is an important part of the mental state examination, particularly of patients with psychosis. Whether to admit, whether to detain and whether to medicate hinges on the apparent presence or absence of insight. It is difficult to understand the scant attention this issue recetves in the textbooks and revision aids used in preparation for MRCPsych exams. Hopefully the resurgence of interest in the concept of insight (Markova \& Berrios, 1992; David et al, 1995) and the teasing out into separate dimensions of awareness of lllness, ability to relabel psychotic experiences and treatment compliance (David, 1990) will lead to improvements in future editions. Meanwhile, we would commend these papers as a thoughtprovoking introduction to a complex but essential area of clinical psychiatry.

DAVD, A. S. (1990) Inalght and psychools. Brttish Joumal of Psychlatry. 166, 798-808.

-. VAN OS, J., JONES, P., et al (1995) Insight and poychotic illness: cross-sectional and longtudinal associations. Brttsh Journal of Psychlatry. 167, 621-628.

MARKOVA, I. S. \& BERPIOS, G. E. (1992) The meaning of insight in clinical poychiatry. Brittsh Journal of Psychlatry, 160, 850-860.

ALEX BALDACCHINO

Fulbourn Hospital, Cambridge

GRAEME YORSTON

Amersham Hospital, Buckinghamshire

\section{Sib-pairs with poychosis}

Sir: My colleagues and I are conducting largescale molecular genetic studies of both schizophrenia and bipolar affective disorder. We are currently trying to identify pairs of affected siblings where both have either schizophrenia or bipolar disorder. Our studies require several hundred pairs of both types. Participants are asked to undergo a standardised psychiatric assessment using a SCAN interview schedule (Wing et al, 1990) and to give a small blood sample for DNA analysis. If the patient does not wish to give blood then sufficient DNA can be extracted from a buccal smear.

I would be most grateful if any psychiatrists who know of suitable sib-pairs would contact me at the address below. Members of our research team will be able to visit the affected individuals to conduct the interviews and to obtain samples. Your help in this important project would be very much appreciated.

Wing. J. K. et al (1990) SCAN: Schedules for Clinical Assessment in Neuropsychiatry. Archives of General Psychiatry, 47, 589-593.

MichAEL J. OWEN

University of Wales College of Medictne, Heath Park, Cardiff CF4 4XN

\section{Clinical practice guidelines}

Sir: Palmer (Psychiatric Bulletin, January 1996, 20, 40-42) presents a useful insight into the rationale behind the development of the first of the clinical practice guidelines (CPGs) by the College. Such a survey reflects the importance of involving 'end users' in all phases of development (i.e. psychiatrists of all grades and other professionals who will be involved in implementation).

A systematic review of all the avallable research evidence into the effectiveness of CPGs in improving clinical practice has been produced (Effective Health Care, 1994). It concluded that good research evidence exists to demonstrate that guidelines can change clinical practice to improve patient outcome, and that "the methods of development, implementation and monitoring of guidelines influence the likelihood of adherence". For such guidelines to be effective, they should be based on the systematic identification and synthesis of evidence of clinical and cost 